\title{
The Flypaper and Teflon Effects: Evidence from China*
}

\author{
Lyoe Lee, Guillermo Vuletin \\ Colby College, Waterville, USA \\ Email:" gvuletin@colby.edu
}

Received August 23, 2012; revised September 28, 2012; accepted October 9, 2012

\begin{abstract}
In this paper, we analyze how public spending responds to income and intergovernmental fiscal transfer shocks in China. Similar to federations around the world, we find the flypaper effect at the provincial level since the country became a de facto federation in 1980. Before 1980 we find what we define as the teflon effect at the central government level. We rationalize the latter regularity using collection costs/distortionary taxation arguments.
\end{abstract}

Keywords: Flypaper Effect; Teflon Effect; Fiscal Federalism; Fiscal Reform; China

\section{Introduction}

The flypaper effect is an empirical regularity that refers to the greater responsiveness of subnational government spending to increases in unconditional intergovernmental transfers (hereafter, fiscal transfers) than to increases in private income. The catchy term "flypaper effect" aims to visualize the idea that money sticks where it hits: money from the private sector (i.e., from private income) tends to be spent in the private sector rather than being taxed away, while money from the public sector (i.e., from fiscal transfers) tends to be spent by the public sector rather than being rebated to citizens. This well-known regularity is observed in many federations and at various levels of subnational government.

We focus our analysis on China. Since its foundation in 1949 this unitary country has witnessed an intense process of fiscal policy transformation regarding how competencies (i.e., expenditure) and fiscal instruments (i.e., revenue) are allocated across different vertical levels of the government. For the period 1949-1979, government spending was heavily centralized and an important bulk of provincial own revenues was remitted to the central government. Figure 1 shows that during this period central government spending represented, on average, 72 percent of consolidated spending, and central government revenues accounted for 59 percent of consolidated revenues. This gap was financed with intergovernmental transfers from provinces. As Figure 2 shows,

\footnotetext{
${ }^{*}$ We are grateful to Samara Gunter, Simge Tarhan, Bradley Turner, Andreas Waldkirch, and seminar participants at the 2011 Colby-BatesBowdoin Annual Economics Conference for helpful comments and suggestions.

\#Corresponding author.
}

provinces remitted 42 percent of their own revenues to the central government.

Researchers agree that China started to shift towards a de facto federation in the early 1980 s, when the central government initiated a wave of expenditure decentralization, providing provinces with more discretion over their budget [1-5]. At the same time, revenue collection became increasingly centralized. Figure 1 shows that the degree of spending centralization decreased from about 70 percent in early 1970 s to 60 percent in early 1990 s and further down to 55 percent for late 2000s. On the contrary, the degree of revenue centralization increased from 55 percent in early 1970s to 60 percent in early 1990s and further up to about 70 percent for late 2000s. Indeed, Figure 2 shows that provinces continuously transformed from net remitters of fiscal transfers to net receivers, starting in $1980^{1}$.

Following the 1994 co-participation and tax reforms, central government transfers account for about 64 percent of provinces' spending financing. This figure coincides with that of federations (40 percent in Argentina and 60 percent in South Africa and Spain).

Exploiting this intense fiscal policy transformation, our paper analyzes how public spending responds to income and fiscal transfer shocks. We analyze the behavior of the central government's spending for the period 1952-1979 and provinces for the period 1980-2008. In each case, own taxation and fiscal transfers financed a majority of public spending. While we observe the fly-

\footnotetext{
${ }^{1}$ The exact transition year from negative to positive provincial vertical fiscal imbalance varies by province. However, with the exception of few moderate/low income provinces, all of provinces made the definitive transition after 1980 .
} 


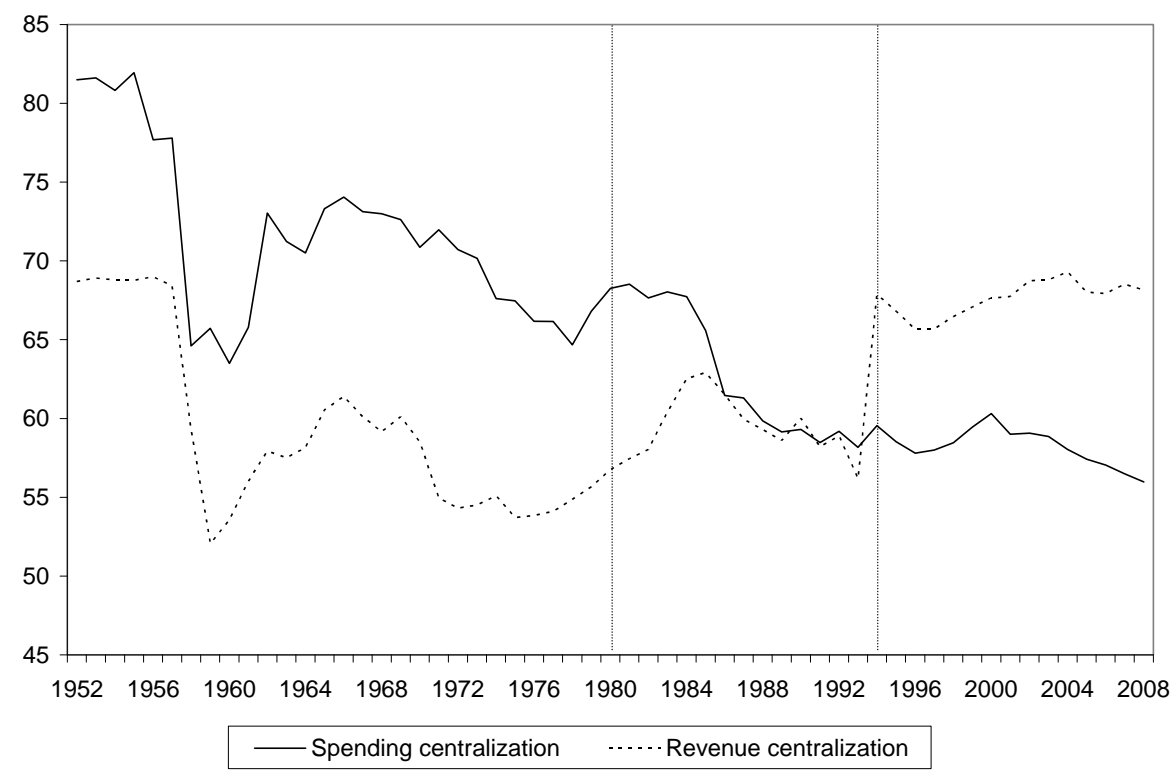

Note: The vertical dashed lines represent years 1980 and 1994.

Figure 1. Centralization of government spending and revenues. Central government spending and revenues as percentage of consolidated (central and provincial) spending and revenues. 1952-2008.

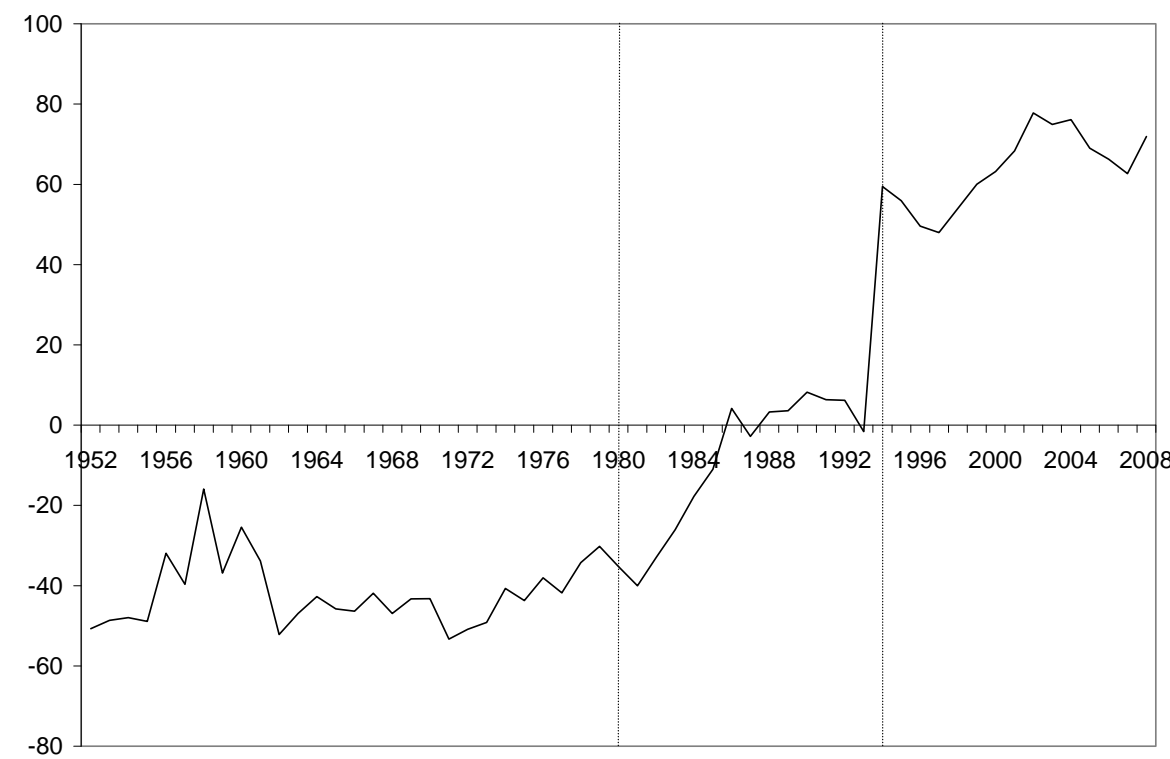

Note: The vertical dashed lines represent years 1980 and 1994. Negative (positive) values indicate provinces net remitting (receiving) transfers to (from) the central government.

Figure 2. Provinces vertical fiscal imbalance. Provinces fiscal transfers as percentage of own revenues. 1952-2008.

paper effect at the provincial level after 1980, before 1980 we find what we define as the teflon effect at the central government level. We rationalize the latter regularity using collection costs/distortionary taxation arguments.

\section{Data}

Our annual panel dataset consists of government revenue, expenditure, intergovernmental net transfers, population, and population density at both the provincial (31 provinces) and national level for the period 1952-2008 ${ }^{2}$. We obtained data from China Data Center (http://chinadataonline.org).

${ }^{2}$ The 31 provincial level division units included in our data include 22 provinces (Anhui, Fujian, Gansu, Guangdong, Guizhou, Hainan, Hebei, Heilongjiang, Henan, Hubei, Hunan, Jiangsu, Jiangxi, Jilin, Liaoning, Qinghai, Shaanxi, Shandong, Shanxi, Sichuan, Yunnan, and Zhejiang), four municipalities (Beijing, Chongqing, Shanghai, and Tianjin), and five autonomous regions (Guangxi Zhuang, Inner Mongolia, Ningxia Hui, Xinjiang Uighur, and Tibet). 
Extrabudgetary funds, which is capital used for specific projects assigned by the central government, are excluded.

\section{Flypaper Effect Evidence (1980-2008)}

Table 1 shows the regressions for Chinese provinces for the period 1980-2008. We consider the following basic specification:

$$
g_{i t}=\beta+\beta_{y} y_{i t}+\beta_{f} f_{i t}+\varepsilon_{i t},
$$

where $g, y$ and $f$ represent government spending, output, and fiscal transfers all expressed in real and per capita terms. Column 1 reports basic Ordinary Least Squares regressions without controls and assuming that the residuals are homoscedastic and have no autocorrelation. The marginal propensity to spend out of fiscal transfers is clearly larger than for local output; there is a flypaper effect.

The regression reported in Column 2 allows for heteroscedasticity and autocorrelation. Column 3 allows for provincial fixed effect and Column 4 also includes year dummies to reduce the omitted variable bias that may occur as a consequence of the processes of decentralization. Column 5 controls for population density, a typical variable used to proxy for cost of provision of public goods. This variable is expected to have a negative sign as such cost is expected to decrease with higher population concentrations ${ }^{3}$. Columns 6 and 7 split the sample into before and after the 1994 co-participation and tax reforms. In every case the flypaper effect remains a strong empirical regularity with a size close to 0.9 . This novel finding for Chinese provinces coincides with that of federations.

\section{Teflon Effect Evidence (1952-1979)}

Table 2 shows the regressions for the central government for the period 1952-1979. We find that, even after relaxing the assumption of homoscedasticity, the marginal propensity to spend out of fiscal transfers is clearly smaller than national output.

This finding is the opposite to the one of Section 3 at the provincial level and novel in nature. No previous study found that government spending responds less to an increase in fiscal transfers than to an equal increase in private income. We define this novel regularity teflon effect. The term teflon effect aims to visualize the idea that, contrary to the flypaper effect, money tends to slide from where it hits: money from the private sector (i.e., from private income) is taxed and mostly allocated to public spending, while money from the public sector (i.e., from provincial fiscal transfers) tends not to be spent and,

\footnotetext{
${ }^{3}$ The estimated coefficient for population density would become nega-
} tive if year dummies were not included. therefore, rebated to citizens ${ }^{4}$. In particular, while an increase of $\$ 1$ in national income raises central government spending by $\$ 0.6$, an equivalent increase in fiscal transfers from provinces only triggers into an increase of $\$ 0.015$ in expenditures. Therefore, the size of the teflon effect is 0.586 .

\section{Rationalizing the Teflon Effect}

This section develops a simple optimal fiscal policy model that rationalizes the teflon effect using the collection cost/distortionary taxation arguments developed by Hamilton (1986) [6], Aragón (2009) [7], and Vegh and Vuletin (2012) [8] to rationalize the flypaper effect. These papers show that the flypaper effect occurs because subnational tax collection has higher collection costs or are more distortionary than the central government.

The endowment economy is inhabited by a benevolent fiscal authority (FA) and a representative citizen (RC) blessed with perfect foresight. Without the loss of generality and in order to obtain analytical solutions, we use $\log$ preferences for RC's utility function:

$$
W=\ln (g)+\ln (c),
$$

where $c$ is private consumption and $\mathrm{g}$ is public spending.

The RC's budget constraint is given by

$$
y=c+\tau,
$$

where $y$ is output and $\tau$ is lump sum tax collection.

Because the central government has two sources of financing, own revenues and fiscal transfers, the central FA's budget constraint is given by

$$
g=\tau(1-\alpha)+f(1-\tilde{\alpha})
$$

where $f$ is total provincial fiscal transfers to the central government. $\alpha$ and $\tilde{\alpha}$ are the central government and effective provincial collection cost/distortionary taxation $\left(\tilde{\alpha} \equiv \sum_{i}\left(f_{i} / f\right) \alpha_{i}\right)$. Hamilton (1986) [6] rationalizes them as the real costs of distortionary taxation, while Aragón (2009) [7] treats them as pure collection costs.

Solving the model we get

$$
g=\frac{1}{2}[(1-\alpha) y+f(1-\tilde{\alpha})] .
$$

From expression (5) we obtain

$$
\frac{1-\tilde{\alpha}}{2}=\frac{\mathrm{d} g}{\mathrm{~d} f}=\frac{\mathrm{d} g}{\mathrm{~d} y}=\frac{1-\alpha}{2},
$$

which states that the relative optimal response of public spending to each type of shock crucially depends upon

${ }^{4}$ Naturally, funds are actually not rebated via checks or financial deposits but they rather decrease the amount being taxed in net terms. 
Table 1. Flypaper effect evidence. 1980-2008. Dependent variable is real per capita provincial expenditure.

\begin{tabular}{|c|c|c|c|c|c|c|c|}
\hline & (1) & (2) & (3) & (4) & (5) & (6) & (7) \\
\hline$y$ & $\begin{array}{c}0.127^{* * *} \\
{[75]}\end{array}$ & $\begin{array}{c}0.127^{* * *} \\
{[8.06]}\end{array}$ & $\begin{array}{c}0.133^{* * *} \\
{[5.7]}\end{array}$ & $\begin{array}{c}0.168^{* * *} \\
{[6.5]}\end{array}$ & $\begin{array}{c}0.160^{* * *} \\
{[5.3]}\end{array}$ & $\begin{array}{c}0.079^{* * *} \\
{[3.93]}\end{array}$ & $\begin{array}{c}0.162^{* * *} \\
{[5.1]}\end{array}$ \\
\hline$f$ & $\begin{array}{c}0.883^{* * *} \\
{[45.1]}\end{array}$ & $\begin{array}{c}0.883^{* * *} \\
{[15.1]}\end{array}$ & $\begin{array}{c}0.772^{* * *} \\
{[5.7]}\end{array}$ & $\begin{array}{c}1.019^{* * *} \\
{[24.3]}\end{array}$ & $\begin{array}{c}1.059^{* * *} \\
{[35.8]}\end{array}$ & $\begin{array}{c}0.849^{* * *} \\
{[30.2]}\end{array}$ & $\begin{array}{c}1.0026^{* * *} \\
{[28.9]}\end{array}$ \\
\hline pop. density & & & & & $\begin{array}{c}4.761^{* * *} \\
{[1.1]}\end{array}$ & $\begin{array}{c}-2.650^{* * *} \\
{[-2.9]}\end{array}$ & $\begin{array}{c}7.970^{* * *} \\
{[1.4]}\end{array}$ \\
\hline \multicolumn{8}{|l|}{ Flypapr effect } \\
\hline absolute size $=\beta_{f}-\beta_{y}$ & $0.756^{* * *}$ & $0.756^{* * *}$ & $0.639^{* * *}$ & $0.851^{* * *}$ & $0.899^{* * *}$ & $0.77^{* * *}$ & $0.864^{* * *}$ \\
\hline test $\beta_{f}=\beta_{y}(\mathrm{p}$-value $)$ & $5.85 \times 10^{-173}$ & $4.55 \times 10^{-12}$ & 0.0002 & $1.48 \times 10^{-18}$ & $4.42 \times 10^{-19}$ & $3.41 \times 10^{-17}$ & $1.96 \times 10^{-16}$ \\
\hline \multicolumn{8}{|l|}{ Statistics } \\
\hline Econometric methodology & OLS & OLS & FE & FE & $\mathrm{FE}$ & FE & $\mathrm{FE}$ \\
\hline Standard errors & Standard & Robust-Cluster & Robust-Cluster & Robust-Cluster & Robust-Cluster & Robust-Cluster & Robust-Cluster \\
\hline Year dummies & No & No & No & Yes & Yes & Yes & Yes \\
\hline Observations & 736 & 736 & 736 & 736 & 736 & 275 & 445 \\
\hline Provinces & 31 & 31 & 31 & 31 & 31 & 24 & 31 \\
\hline Period & $1980-2008$ & $1980-2008$ & $1980-2008$ & $1980-2008$ & $1980-2008$ & $1980-1993$ & $1994-2008$ \\
\hline $\mathrm{R}^{2}$ & 0.934 & 0.934 & 0.928 & 0.955 & 0.957 & 0.928 & 0.962 \\
\hline
\end{tabular}

Note: $f$ stands for real per capita provincial fiscal transfers from central government. $y$ stands for real per capita provincial gross domestic product. Only observations where $f>0$ were included in regressions. Constant term is not reported. OLS stands for Ordinary Least Squares. FE stands for panel data provincial fixed effect. $\mathrm{R}^{2}$ correspond to within $\mathrm{R}^{2} .^{*},{ }^{* *}$ and ${ }^{* * *}$ denote significance at $10 \%, 5 \%$ and $1 \%$ levels, respectively.

Table 2. Teflon effect evidence. 1952-1979. Dependent variable is real per capita central government expenditure.

\begin{tabular}{lcc}
\hline & $(1)$ & $(2)$ \\
\hline$y$ & $0.601^{* * *}$ & $0.601^{* * *}$ \\
$f$ & {$[11.8]$} & {$[8.1]$} \\
& $0.015^{* * *}$ & $0.015^{* * *}$ \\
pop. density & {$[3.4]$} & {$[3.9]$} \\
Teflon effect & $-15.030^{* * *}$ & $-15.030^{* * *}$ \\
absolute size $=\beta_{f}-\beta_{y}$ & {$[-7.4]$} & {$[-4.6]$} \\
test $\beta_{f}=\beta_{y}$ (p-value) & $0.586^{* * *}$ & $0.586^{* * *}$ \\
Statistics & $4.10 \times 10^{-11}$ & $3.12 \times 10^{-8}$ \\
Econometric methodology & & \\
Standard errors & OLS & OLS \\
Observations & Standard & Robust \\
Period & 28 & 28 \\
$\mathrm{R}^{2}$ & $1952-1979$ & $1952-1979$ \\
\hline
\end{tabular}

Note: $f$ stands for real per capita central government fiscal transfers from provincial governments. $y$ stands for real per capita country gross domestic product. Only observations where $f>0$ were included in regressions. Constant term is not reported. OLS stands for Ordinary Least Squares. $\mathrm{R}^{2}$ correspond to within $\mathrm{R}^{2} .^{*},{ }^{* *}$ and ${ }^{* * *}$ denote significance at $10 \%, 5 \%$ and $1 \%$ levels, respectively. the collection cost/distortionary taxation associated with each of them. If $\tilde{\alpha}>\alpha$,

$$
\frac{1-\tilde{\alpha}}{2}=\frac{\mathrm{d} g}{\mathrm{~d} f}<\frac{\mathrm{d} g}{\mathrm{~d} y}=\frac{1-\alpha}{2},
$$

That is to say, the optimal response supports the teflon effect. This occurs because the central government internalizes that spending out of provincial fiscal transfers is more costly than spending out of their own revenue. The opposite would be true if $\alpha>\tilde{\alpha}$.

The public finance literature supports that $\alpha>\tilde{\alpha}$. Rubinfield (1983) [9] argues that revenue collection should be centralized to take full advantage of administrative economies of scale in the collection of taxes. Buchanan (1950) [10] and Hamilton (1986) [6] argue that central government taxation is less distortionary than subnational one, among other reasons because of tax base mobility. These are, among others, the main reasons why most federations have leaned to centralize tax collection.

Chinese evidence points in the same direction. Figure 3 shows that collection costs, proxied by the ratio of administrative spending over total spending, for provinces $(0.14)$ are almost three times higher than those of the central government (0.06). Following, among others, Barro (1991) [11] and Jin and Zou (2005) [2] we proxy tax distortion using tax burden which is measured as the ratio of revenues to GDP. Figure 4 shows that the effec- 


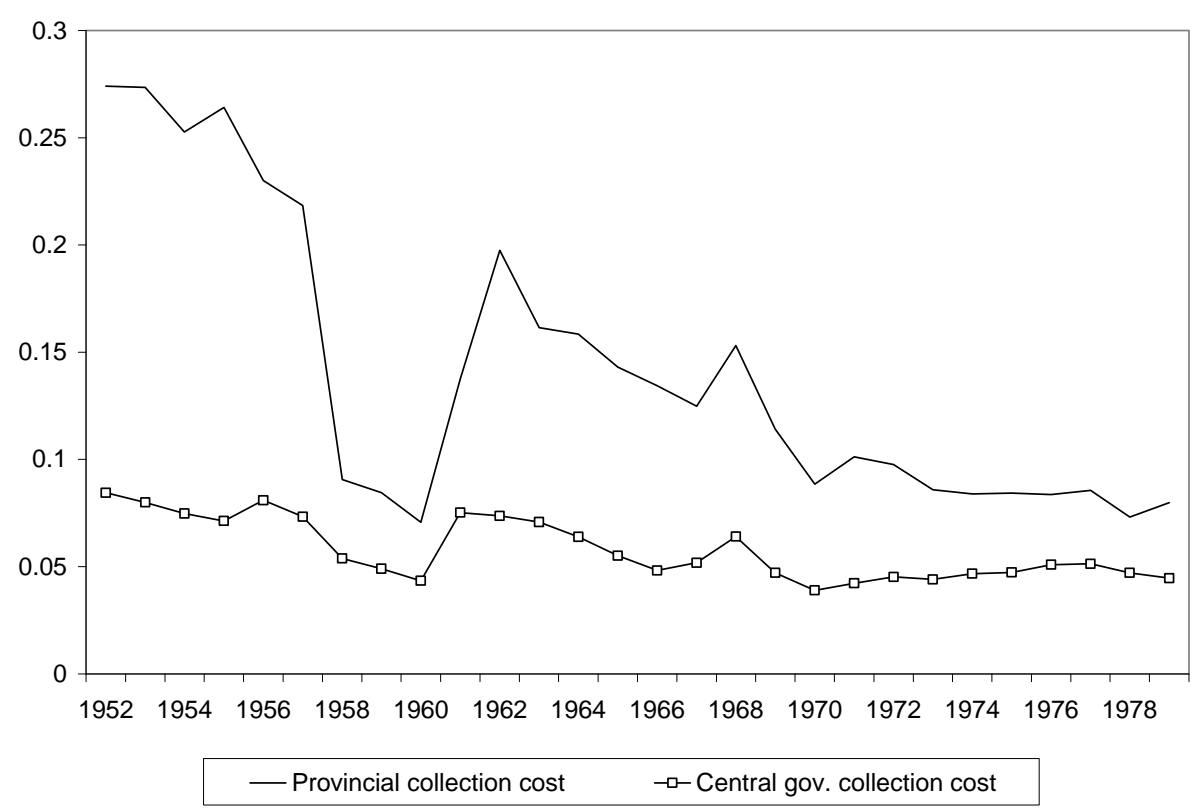

Note: Provincial (central government) collection cost is calculated as the ratio of total administrative provincial (central government) spending over total spending.

Figure 3. Provincial and central government collection costs. 1952-1979.

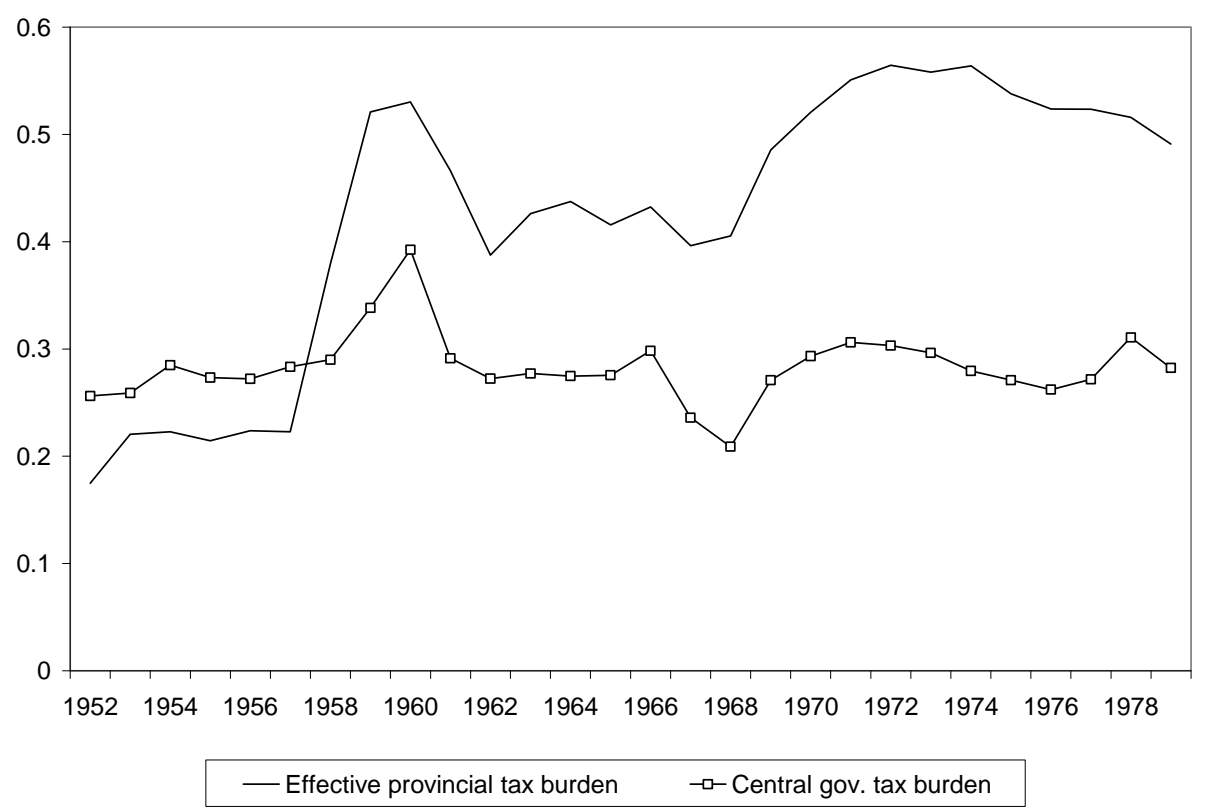

Note: Effective provincial tax burden is calculated as the weighted average of each province tax burden. The weight used in each case correspond to the relative importance of each province transfers in the total of transfers.

Figure 4. Effective provincial and central government tax burdens. 1952-1979.

tive tax distortion imposed by provinces $(0.42)$ is, indeed, almost two times bigger than that of central government (0.28). To sum up, both literature consensus as well as some empirical evidence support the rationalization of the teflon effect through the eyes of collection cost/distortionary taxation arguments.

\section{Conclusion}

Exploiting the intense fiscal policy transformation witnessed in China during the last six decades, our paper unravels two novel findings. First, we observe the flypaper effect at the provincial level since the country became a de facto federation in 1980. Second, we find what 
we define as the teflon effect at the central government level prior to 1980 . We rationalize the latter regularity using collection costs/distortionary taxation arguments used by the literature of the flypaper effect.

\section{REFERENCES}

[1] M. Su and Q. Zhao, "China's Fiscal Decentralization Reform," The Research Institute for Fiscal Science, Ministry of Finance, China, 2004.

[2] J. Jin and H. Zou, "Fiscal Decentralization, Revenue and Expenditure Assignments, and Growth. China," Journal of Asian Economics, Vol. 16, No. 6, 2005, pp. 1047-1064. doi:10.1016/j.asieco.2005.10.006

[3] R. Bird and C. P. Wong, "China's Fiscal System: A Work in Progress," International Studies Program, Andrew Young School of Policy Studies, Georgia State University, Atlanta, 2005.

[4] K. Tochkov, "Interregional Transfers and the Smoothing of Provincial Expenditure in China," China Economic Review, Vol. 18, No. 1, 2007, pp. 54-65.

doi:10.1016/j.chieco.2006.09.002
[5] C. H. Chen and H. Wu, "Fiscal Structures and Regional Economic Growth: Evidence from China's Fiscal Contract System," The Journal of Developing Areas, Vol. 41, No. 2, 2008, pp. 119-135. doi:10.1353/jda.2008.0025

[6] J. H. Hamilton, "The Flypaper Effect and the Deadweight Loss from Taxation," Journal of Urban Economics, Vol. 19, No. 2, 1986, pp. 148-155. doi:10.1016/0094-1190(86)90036-7

[7] F. Aragón, "The Flypaper Effect and Costly Tax Collection," Mimeo, School of Economics, London, 2009.

[8] C. Vegh and G. Vuletin, "Unsticking the Flypaper Effect Using Distortionary Taxation," Mimeo, University of Maryland and Colby College, Waterville, 2012.

[9] D. Rubinfield, "Tax Assignment and Revenue Sharing in the United States," In: R. Mathews and C. McLure, Eds., Tax Assignment in Federal Countries, Australian National University Press, Canberra, 1983, pp. 205-233.

[10] J. Buchanan, "Federalism and Fiscal Equity," American Economic Review, Vol. 40, 1950, pp. 583-599.

[11] R. J. Barro, "Government Spending in a Simple Model of Endogenous Growth," NBER Working Paper, No. 2588, 1991. 